with first-class honours in 1943. He then joined the Royal Navy as midshipman and successively became sub-lieutenant and lieutenant, his main concern being with anti-submarine warfare. $\mathrm{He}$ returned to the staff of the Department in 1946, and was appointed senior lecturer in 1953. His first researches were in the field of electron optics, but in 1947 he began to take an interest in servo-mechanisms. During the ten years that have elapsed since then he has built up an active research group specializing mainly in non-linear servo-mechanisms. Dr. West has become a well-known authority in this difficult field, to which he, and his group, have contributed a considerable body of published work. Arising out of this work he was awarded the degrees of Ph.D. in 1952 and D.Sc. in 1957. Alongside this research activity he has built up an excellent third-year undergraduate course. In connexion with this course he has published a very successful text-book and he has a further book in course of publication. Dr. West's activities extend well beyond purely academic circles : he is a member of several committees concerned with automatic control and is in close touch with industry through his consulting activities. $\mathrm{He}$ has taken an active part in the work of the Institution of Electrical Engineors and received a Premium of the Institution in 1956 for his work on non-linear control systems. He has been a member of the North-Western Centre Measurement and Control Section Committee, of which he was chairman during 1955-56, and has been an invited speaker at several international conferences on automatic control.

Biohistorical Institute of the University of Utrecht : Dr. Frans Verdoorn

Dr. Frans Verdoorn, managing editor of the Chronica Botanica Co. and secretary of the International Biohistorical Commission, has been appointed director of the new Biohistorical Institute of the University of Utrecht, Tho Netherlands. This Institute, now being sot up in conjunction with Prof. Lanjouw's Botanical Museum and Herbarium, will concern itself with the cultural, historical, other humanistic and related aspects of the pure and applied sciences of life, with special reference to the plant species. Born in The Netherlands and originally a cryptogamic botanist, Dr. Verdoorn later engaged mainly in editorial and international relations work. After moving to the United States in 1940, his main interests turned gradually to the borderlands between the natural sciences and tho humanities and he collected a great deal of information on botanical biography ("Index Botanicorum"), the history of biology, the history of botanic gardens, the Linnæan period, ete., which will now form the nucleus of the new Institute at Utrecht.

\section{Centenary of the British Ornithologists' Union}

As part of its centenary celebrations the British Ornithologists' Union (founded 1858-59) is placing two scientific expeditions in the field. The main expedition is to Ascension Island, where a party of four will undertake a thorough examination of the general biology and breeding behaviour of the ten species of sea birds present. Particular attention will be paid to the following points : investigation of the factors influeneing the timing of the breeding seasons (known to fall every nime months in one species) ; comparisons of the feeding, growth, matura- tion and survival-rates of the young; comparative studies of behaviour patterns in closely related species ; population counts and surveys of breeding sites, as a basis for conservation measures and possible future studies; an extensive programme of ringing adults and young. The party left England recently and expects to remain in the field for eighteen months. It will be joined from time to time by visiting scientists, who will work on independent problems. The expedition, which is led by Bernard Stonehouse, of the Edward Grey Institute, Oxford, who has had long experience of biological and meteorological work in Antarctica and Grahamland, will also be taking hydrographic observations. A second expedition is planned to investigate problems of taxonomics and speciation in the Comoro Islands.

\section{Scientific and Technical Man-power in Britain}

Several questions relating to scientific man-power were raised in the House of Commons during November 18-19. The Paymaster-General gave the number of scientists now employed in his Department as 162 and his expenditure on scientific research in the current financial year as $£ 1,045,000$. Asked whether he would arrange for one Government department to be responsible for maintaining records of the numbers, qualifications and types of appointment held by professional engineers and technologists, the Prime Minister said that the Minister of Labour is already responsible for collecting information about the employment of persons in Great Britain, including engineers and technologists, and that the expense of keeping records as full as those suggested would be disproportionate to the value. Asked if he would arrange for one Government department to be responsible for maintaining records of all emigration of highly qualified scientists and engineers, the Prime Minister referred to an earlier reply of the Home Secretary which stated that in view of admitted deficiencies in the available statistics of emigration to and from the United Kingdom, Government departments interested are making a special review of the information required for official purposes about migration and the means for obtaining it. In reply to a further question as to the accuracy and fullness of the records of emigration, the Prime Minister emphasized the difficulty of obtaining the records, which are undoubtedly desirable, without resorting to compulsory registration, for example; he said he is ready to seek all possible information short of reverting to compulsory powers. On November 20 , the Minister of Labour said, in answer to a question whether he would now grant exemption from National Service to science and engineering graduates with second-class honours degrees entering establishments of further education, that he had asked his Technical Personnel Committee to study the proposal.

\section{Russian Scientific Literature}

Tus Department of Scientific and Industrial Research Lending Library Unit is building up a comprehensive collection of Russian scientific and technological literature. At present it is roceiving some 220 periodicals regularly from the U.S.S.R. In addition it has received parts of a number of irregular serials, and has catalogued more than 500 Russian books. In all it is probably receiving something over half the current Russian output of scientific and technical literature. The rest is in the 